\title{
Storage Variability among Short-day Onion Cultivars under High Temperature and High Relative Humidity, and its Relationship with Disease Incidence and Bulb Characteristics
}

\author{
Swee-Suak Ko ${ }^{1}$ \\ Asian Vegetable Research and Development Center, P.O. Box 42, Shanhua, Tainan, Taiwan 741, \\ Republic of China \\ Woo-Nang Chang ${ }^{2}$ \\ Department of Horticulture, National Chung Hsing University, Taichung, Taiwan 402, Republic of China \\ Jaw-Fen Wang, ${ }^{3}$ Shin-Jiun Cherng, ${ }^{4}$ and S. Shanmugasundaram ${ }^{5}$ \\ Asian Vegetable Research and Development Center, P.O.Box42 Shanhua, Tainan, Taiwan 741, Republic \\ of China
}

\begin{abstract}
AdDitional INDEX wORDS. Allium cepa, bacterial soft rot, black mold, fusarium basal rot, onion storability, postharvest diseases

ABstract. In the tropics, onion (Allium cepa L.) bulbs are usually stored in shelters under ambient conditions resulting in severe storage losses. This study was aimed at determining whether variation in bulb storability exists among shortday onion cultivars and whether the trait can be improved through conventional breeding. Twelve onion cultivars with different degrees of storability were selected from preliminary experiments. Bulbs of selected cultivars were grown and stored for 3 months under ambient conditions. Observations were made on disease incidence at harvest, percentage diseased bulbs, and storage disease incidence of bacterial soft rot [BR (Pseudomonas gladioli pv. alliicola Burkholder)], black mold [BM (Aspergillus niger Tiegh.)], and fusarium basal rot (F usarium oxysporum Schlechtend.:Fr. f. sp. cepae) after 3 months of storage. Data on bulb characteristics such as bulb fresh weight (FW), dry matter (DM) content, total soluble solids (TSS), and pyruvic acid content were recorded at harvest. Mean storage losses of cultivars ranged from $21 \%$ to $99 \%$ over 3 years. Diseases were the major causes of storage losses, with BR and BM being the most predominant. Performance of most traits (including storage losses) was significantly influenced by year (Y), cultivar $(G)$, and $Y \times G$ interaction. Heavy rainfall during bulb development in 1997 may have contributed to higher disease incidence at harvest, higher percentage of diseased bulbs during storage, and lower DM, and TSS of the cultivars. Cultivars with good storability, such as 'Red Pinoy' and 'Serrana', were less sensitive to stressful environments and high disease pressure. Incidence of storage diseases was significantly correlated with DM $(r=-0.65$ to -0.84$)$ and TSS $(r=-0.66$ to -0.87$)$, as well as incidence of $\mathrm{BR}(r=0.57$ to 0.94$)$ in each year. Thus, they could be good indicators for evaluating storability. Cultivars with good storability tended to have small bulbs, as average bulb FW was positively correlated with incidence of storage diseases. Disease incidences on 'Red Pinoy' and 'Serrana', both in the field and in storage, were significantly lower than in the other cultivars, indicating they are tolerant to major storage diseases and that they could be used as donor parents for genetic improvement of onion storability.
\end{abstract}

In the tropics, onions (Allium cepa) are produced during the cool-dry season and stored by farmers during the hot-wet season (Currah and Proctor, 1990). Although onions are less perishable than many other vegetables, storage losses in the tropics can be as high as $50 \%$ (Musa et al., 1973). Storing onions at 0 to $2{ }^{\circ} \mathrm{C}$ and $65 \%$ relative humidity $(\mathrm{RH})$ will minimize storage losses (Handenburg et al., 1986; Tanaka et al., 1985). However, refrigerated storage facilities are often too expensive for farmers in these regions. Therefore, onions are stored mostly in shelters at

Received for publication 12 Mar. 2001. Accepted for publication 16 April 2002. Journal paper no. 168 of the Asian Vegetable Research and Development Center (AVRDC). This paper is based on a portion of a $\mathrm{PhD}$ dissertation. by S.-S.K. The authors are grateful to the Natural Resources Institute, United Kingdom, for the onion germplasm used in this study. We are also grateful to the Nutrition and Analytical Laboratory at AVRDC for conducting the chemical analysis. Assistance of C.S. Pathak in planning the study is acknowledged. We thank D.R. Ledesma for assistance in statistical analysis.

${ }^{1}$ Assistant specialist.

${ }^{2}$ Professor.

${ }^{3}$ Associate plant pathologist.

${ }^{4}$ Assistant specialist.

${ }^{5}$ Plant breeder. ambient conditions. A survey of specific problems dealing with onion production and storage in tropical and subtropical regions by Currah and Proctor (1990), indicated that onion storage losses were serious in 44 out of 72 tropical countries. Survey respondents in most of the Asian countries (19 out of 21) reported high onion storage losses. Diseases were the primary problem, with sprouting being the secondary factor that limited storage under tropical conditions (Currah and Proctor, 1990).

Onion storability is affected by environmental, pathogenic, and genetic factors. Hot and humid conditions promote development of storage diseases such as black mold [BM (Aspergillus niger)] (Tanaka, 1991; Yoo et al., 1989), fusarium basal rot [FR (Fusarium oxysporum: Fr. f. sp. cepae)] (Lorbeer and Stone, 1965), and bacterial soft rot [BR (Pseudomonas gladioli pv. alliicola)] (Wall and Corgan, 1994; Wright, 1993; Vitanov, 1976).

Several researchers have attempted to relate bulb characteristics with storage life and reported that dry matter (DM), total soluble solids (TSS), pungency, and dry scale number are associated with storage life of onions (Currah and Proctor, 1990; Sato 
and Nagai, 1997). Pal et al. (1988) indicated that high DM content in onion was negatively correlated with storage loss, but positively correlated with TSS, pungency, total sugars and nonreducing sugars. It was observed that cultivars with good storability tend to have high pyruvic acid levels and low amounts of reducing sugars (Chang, 1976).

All onions are day-length sensitive. Short-day onions adapted to the tropics or subtropics require a photoperiod slightly $>12 \mathrm{~h}$ for bulb development. Although long-day cultivars tend to have longer storage life than short-day cultivars (Brice et al., 1997), storability varies significantly among short-day cultivars. For example, 'Early Grano' and 'Granex' onions can be stored for only 1.6 months, whereas 'Red Creole' can be stored for 2 to 6 months. Other short-day cultivars such as 'Violet de Galmi', 'XP8403'/'Serrana', 'Yod Aleph', and 'HA232', store for up to 7 months with $<40 \%$ loss (Currah and Proctor, 1990).

Many factors affect onion storability, and finding a good indicator for selection before storage trials would improve breeding efficiency. Although several studies have documented onion storage losses (Suzuki and Cutcliffe, 1989; Tucker and Drew, 1982), research to elucidate the relationship among production environment, storage loss, and other bulb characteristics is lacking. Therefore, this study was conducted to 1) evaluate variation in storability among short-day onion cultivars, 2) identify factors responsible for onion storage losses over years, and 3) determine the relationship between storage loss and bulb characteristics.

\section{Materials and Methods}

Preliminary evaluation of storability among onion cultivars

A total of 130 short-day onion cultivars from different sources were evaluated for storability (Table 2-1; Ko, 2001). Seedlings were transplanted on 10 Nov. 1993 at the experimental farm of the Asian Vegetable Research and Development Center (AVRDC), Shanhua, Taiwan, Republic of China. The soil was Fluventic Dystrochrept, a sandy loam and contained $1.5 \%$ organic matter. After plowing, $\mathrm{N}$ (as ammonium sulfate) at $95 \mathrm{~kg} \cdot \mathrm{ha}^{-1}, \mathrm{P}$ (as calcium superphosphate) at $100 \mathrm{~kg} \cdot \mathrm{ha}^{-1}, \mathrm{~K}$ (as potassium chloride) at $30 \mathrm{~kg} \cdot \mathrm{ha}^{-1}$, and organic matter at $200 \mathrm{~kg} \cdot \mathrm{ha}^{-1}$ were broadcast over the experimental area. The field was rototilled and raised beds $0.75 \mathrm{~m}$ in width were prepared. Each bed had two rows and plants were spaced $15 \mathrm{~cm}$ between rows and $10 \mathrm{~cm}$ between plants within rows. Each replication had 60 plants/cultivar. The plot size of each replication was $2.25 \mathrm{~m}^{2}$. A randomized complete block design (RCBD) with three replications was used. Topdressings of $\mathrm{N}, \mathrm{P}$, and $\mathrm{K}$ were applied at 14, 30, and $50 \mathrm{~d}$, respectively, after transplanting. In total, N, P, and K were applied at $168,180,180 \mathrm{~kg} \cdot \mathrm{ha}^{-1}$, respectively. Furrow irrigation was applied every $10 \mathrm{~d}$ and irrigation was discontinued 2 to 3 weeks before harvest. The fungicides Dithane M-45 (enthylene bisdithio carbamate), Iprodione [3-(3,5-dichlorophenyl)-N-(1-methylethyl) 2,4-dioxo-1-imidazoline-carboxamido], and Daconil (tetrachloroisophthalonitrile) were applied as a mixed spray to control foliar diseases. The insecticide Decis [(1R, 3R)-3(2,2dibromovinyl-2,2-dimethylcyclopropane-carboxylic acid (S)-alpha-cyano-3-phenoxybenzyl ester)], Dimethoate \{0,0-dimethylS-[(methylcarbamoyl)-methyl $]$ phosphorodithioate $\}$, and Trigard (N-cyclopropyl-1,3,5-triazine 2,4,6 triamine) were used to control insects. These pesticides were applied when needed.

Bulbs were harvested during Mar. 1994. Five kilograms of bulbs of each cultivar with no visible disease symptoms were selected and placed in individual nylon mesh bags. The experiment was conducted using a RCBD with three replications. The nylon mesh bags with bulbs were placed on shelves in a concrete storage room, $7.5 \mathrm{~m}$ long $\times 6.5 \mathrm{~m}$ wide $\times 3.5 \mathrm{~m}$ high. Threelayered (40 cm spacing) wooden shelves $(1.98 \mathrm{~m}$ long $\times 0.7 \mathrm{~m}$ wide $\times 1.85 \mathrm{~m}$ high) were installed in the room. The room was ventilated with two standing fans $(60 \mathrm{~cm}$ diameter $)$ and two exhaust fans ( $45 \mathrm{~cm}$ diameter). Bulbs were stored for 3 months at $30 \pm 2{ }^{\circ} \mathrm{C}$ and a $\mathrm{RH}$ of $80 \pm 3.5 \%$. At monthly intervals, sound bulbs were weighed and percentage storage losses determined using $100-$ (sound bulb weight/initial bulb weight $\times 100$ ). Cultivars were categorized into four groups based on storage losses after 3 months: 1) good storability: storage losses <30\%;2) moderate storability: $31 \%$ to $50 \%$ loss; 3 ) poor storability: $51 \%$ to $70 \%$ loss; and 4) very poor storability: $>70 \%$ loss. Mean bulb weight for each cultivar was recorded at harvest and its relationship with storage losses was analyzed using linear correlation.

\section{Evaluation trials of selected cultivars}

Plant material. Twelve onion cultivars with different storability (Table 1) were selected from the preliminary evaluation trial in 1994. Seeds were sown on 7 Oct. 1994, 13 Oct. 1995 , and 20 Oct. 1996, and seedlings transplanted on 28 Nov. 1994, 28 Nov. 1995, and 2 Dec. 1996, respectively, at the AVRDC experimental farm. Trials were arranged in a RCBD with three replica-

Table 1. Source and characteristics of short day onion cultivars used in this study.

\begin{tabular}{|c|c|c|c|c|}
\hline $\begin{array}{l}\text { Cultivar } \\
\text { or line }\end{array}$ & $\begin{array}{l}\text { Source } \\
\text { (seed co.) }\end{array}$ & Origin & $\begin{array}{l}\text { Bulb } \\
\text { color }\end{array}$ & $\begin{array}{l}\text { Bulb } \\
\text { shape }^{z}\end{array}$ \\
\hline Red Pinoy & East-West & Philippines & Red & Flat \\
\hline Serrana/XP8403 (OP) ${ }^{y}$ & Asgrow & USA & Yellow & Globe \\
\hline Texas Grano $1025 \mathrm{Y}$ & Asgrow & USA & Yellow & Globe \\
\hline $\operatorname{Arad}(\mathrm{H})$ & Hazera & Israel & Yellow & Flat globe \\
\hline Galil $(\mathrm{H})$ & Hazera & Israel & Yellow & Globe \\
\hline Early Supreme & Sunseed & USA & White & Globe \\
\hline Dehydrator No.3 & Sunseed & USA & White & Flat \\
\hline AC50 & AVRDC breeding line & India & Yellow & Flat globe \\
\hline Granex $429(\mathrm{H})$ & Asgrow & USA & Yellow & Globe \\
\hline Torrens White & Yates & Australia & White & Flat globe \\
\hline
\end{tabular}

${ }^{\mathrm{z}}$ Bulb shape according to the description of Currah and Proctor (1990).

${ }^{\mathrm{y}} \mathrm{OP}=$ open-pollinated cultivar, $\mathrm{H}=\mathrm{F}_{1}$ hybrid cultivar. 
tions. Plots included a 1-m-wide raised bed with three, 5-m-long rows spaced $15 \mathrm{~cm}$ apart with $10 \mathrm{~cm}$ between plants within rows. Each replication had 150 plants. Cultural conditions were the same as described previously. Bulbs were harvested in mid-April after more than $80 \%$ of the tops had collapsed, and cured in the field for 10 more days until the skin and necks had completely dried. Bulbs were then topped, leaving a 2-cm stalk.

Disease incidence at harvest and DURing STORAge. The number of bulbs showing any disease symptoms was recorded at harvest when yield data were recorded. Percentage disease incidence at harvest was calculated based on the total number of bulbs per plot. Forty healthy uniform bulbs of each cultivar in each replication were placed separately in $36 \times 60 \mathrm{~cm}$ nylon mesh bags. Onion cultivars were arranged in a RCBD with three replications. Initial weight was recorded and bulbs were placed in storage on 16 May 1995 and 1 May 1996 and 1997 under the same ambient storage room conditions described previously. Mean maximum/ minimum air temperatures and mean maximum/minimum $\mathrm{RH}$ during storage were $32.1 \pm 2.6 / 24.5 \pm 1.7^{\circ} \mathrm{C}$ and $97.1 \pm 1.5 / 57.4$ $\pm 12 \%$ in $1995 ; 31.9 \pm 2.2 / 23.8 \pm 1.2^{\circ} \mathrm{C}$ and $97.6 \pm 1.3 / 66.6 \pm 7.5 \%$ in $1996 ; 31 \pm 2.1 / 23.1 \pm 2.4{ }^{\circ} \mathrm{C}$ and $86.8 \pm 5.9 / 64.3 \pm 6.4 \%$ in 1997 , respectively.

Bulbs were stored for 3 months and examined at 3-week intervals. Nonmarketable bulbs were separated from marketable bulbs. The numbers of sprouted and decayed bulbs among nonmarketable bulbs were recorded. Total storage loss was determined as number of nonmarketable bulbs/40 $\times 100$. Marketable sound bulbs were returned to the storage room. Incidences of major diseases were identified following descriptions of Schwartz and Mohan (1995). Bulbs showing water-soaked symptoms and having a foul odor were likely infected by Pseudomonas Burkholder spp. and/or Erwinia carotovora ssp. carotovora (Jones) Bergey et al. and were grouped under BR. BM was recognized by black discoloration on the neck, shallow lesions on outer scales, and streaks of black mycelium and conidia beneath the outer dry scales. FR was identified based on reddish stem discoloration and white mycelium on the basal plate. Incidences of botrytis neck rot (Botrytis allii Munn) and white rot (Sclerotium cepivorum Berk.) were minor and not reported in this study. The percentage of diseased bulbs at the end of 3 months storage was calculated based on the total number of diseased bulbs at the end of storage/initial bulb number $\times 100$.

Bulb CHARACTERISTICS. Five good quality bulbs from each plot were randomly sampled at harvest every year for chemical analysis by the Nutrition and Analytical Laboratory of AVRDC. Before analysis, bulbs were stripped of outer dry scales and cut longitudinally into four parts. Pungency was determined by development of pyruvic acid (PA), following the procedures described by Schwimmer and Weston (1961). Total soluble solids (TSS) were estimated by squeezing the juice from fresh onion tissues using a garlic press onto a hand-held refractometer (Atago, Japan). The remaining bulbs were sliced and a $200 \mathrm{~g}$ sample was dried for $4 \mathrm{~d}$ at $45^{\circ} \mathrm{C}$ followed by $2 \mathrm{~d}$ at $105^{\circ} \mathrm{C}$. The sample was then weighed, and percentage dry matter (DM) content calculated. The initial weight of 40 bulbs per bag was determined before storage and average bulb weight was calculated.

Data Analysis. All percentage data were transformed by arcsine square root transformation before analysis. Data from each year were analyzed separately by analysis of variance (ANOVA). Tests of homogeneity of variance were conducted and data from 3 years were subjected to a combined ANOVA
(SAS Institute Inc., 1993). Partitioning of the sum of squares for cultivar and year $\times$ cultivar interaction effects were carried out by grouping cultivars with similar trends of storage loss across years. Mean separations among cultivars for disease incidence at harvest, disease incidence after 3 months of storage, and for other bulb characteristics were performed using Duncan's multiple range test at $P \leq 0.05$. Pearson correlation coefficients between storage losses and other bulb traits were computed with cultivar entry means in each year $(n=12)$, using Proc Corr of SAS (SAS Inst. Inc., 1993).

\section{Results}

\section{Preliminary evaluation of storability among short-day onion cultivars}

Storage losses among the 130 cultivars varied from $14 \%$ to $100 \%$ after 3 months storage (Ko, 2001). The main cause of storage loss was bulb decay caused by postharvest diseases. The predominant diseases were BR, BM, and FR. Based on their storability, the cultivars could be grouped arbitrarily into four categories (good, moderate, poor, and very poor) (Table 2). The six cultivars with good storability were 'Dehydrator No. 3', 'Creole Red', 'Serrana', 'PSX2789', and 'XPH8407' from the United States, and 'H-675' from Israel. Large variations in bulb size and skin color were observed among the 130 cultivars. Average bulb weight varied from $85 \mathrm{~g}$ to $382 \mathrm{~g}$ among cultivars. Mean and SD of bulb weight for the good storability group was smaller $(135 \pm 37 \mathrm{~g})$ compared with the very poor storability group $(245 \pm 53 \mathrm{~g})$ (Table 2$)$. Storage losses were positively correlated with bulb weight $(r=0.57, P<0.01)$. A total of 98 out of 130 cultivars had yellow skin color, 18 cultivars were red, and 14 were white. Bulb skin color was not associated with storage losses.

\section{Evaluation trials of selected cultivars}

Disease INCIDENCE AT HARVEST. Disease incidence at harvest of the 12 cultivars selected for this study (evaluated in 1995 through 1997) ranged from $0 \%$ to $20.7 \%$ (mean $=5 \%$ ) in 1995 , $0 \%$ to $5.1 \%($ mean $=2.4 \%)$ in 1996 , and $4.3 \%$ to $56.7 \%($ mean $=$ $24.6 \%$ ) in 1997 . Different degrees of variation in disease incidence at harvest were observed for individual cultivars over the years. Four cultivars, Serrana, Red Pinoy, AC50, and Texas Early Grano 502, showed low disease incidence over the three trials. However, at the same time, some cultivars exhibited great storage loss variation. For example, 'Texas Grano 1025Y' and 'Arad' had low disease incidence $(<1.3 \%)$ in 1995 and 1996, but had $>40 \%$ disease incidence in 1997. 'Early Supreme' had the highest disease incidence among the 12 cultivars in 1995 and 1997 ( $20.7 \%$ and $56.7 \%$, respectively), but in 1996 , its disease inci-

Table 2. Number of cultivars and average bulb weight \pm SD of 130 cultivars in different storability categories (Ko, 2001).

\begin{tabular}{lccc}
\hline \hline & $\begin{array}{c}\text { Storage } \\
\text { loss }^{2} \\
(\%)\end{array}$ & $\begin{array}{c}\text { Cultivars } \\
(\text { no. })\end{array}$ & $\begin{array}{c}\text { Avg } \\
\text { bulb wt } \\
(\mathrm{g})\end{array}$ \\
\hline Gategory & $<30$ & 6 & $135 \pm 37$ \\
Moderate & $31-50$ & 13 & $167 \pm 51$ \\
Poor & $51-70$ & 39 & $200 \pm 46$ \\
Very poor & $>70$ & 72 & $245 \pm 53$
\end{tabular}

${ }^{\mathrm{z}}$ After 3 months storage under high temperature $\left(30 \pm 2^{\circ} \mathrm{C}\right)$ and high $\mathrm{RH}$ $(80 \% \pm 3.5 \%)$. 


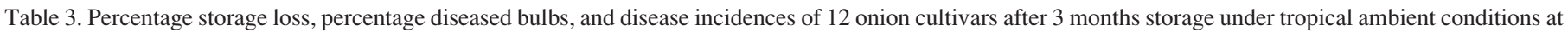
the AVRDC, Tainan, Taiwan, Republic of China.

\begin{tabular}{|c|c|c|c|c|c|c|c|c|c|c|c|c|c|c|c|}
\hline \multirow{3}{*}{$\begin{array}{l}\text { Cultivar } \\
\text { or line }\end{array}$} & \multirow{2}{*}{\multicolumn{3}{|c|}{ Storage loss (\%) }} & \multirow{2}{*}{\multicolumn{3}{|c|}{ Diseased bulbs (\%) }} & \multicolumn{9}{|c|}{ Disease incidence $(\%)$} \\
\hline & & & & & & & \multicolumn{3}{|c|}{ Bacterial soft rot } & \multicolumn{3}{|c|}{ Black mold } & \multicolumn{3}{|c|}{ Fusarium basal rot } \\
\hline & 1995 & 1996 & 1997 & 1995 & 1996 & 1997 & 1995 & 1996 & 1997 & 1995 & 1996 & 1997 & 1995 & 1996 & 1997 \\
\hline Red Pinoy & $21.1 \mathrm{~h}^{\mathrm{z}}$ & $30.0 \mathrm{f}$ & $57.3 \mathrm{e}$ & $18.5 \mathrm{~h}$ & $28.3 \mathrm{f}$ & $58.8 \mathrm{e}$ & $4.2 \mathrm{e}$ & $2.5 \mathrm{f}$ & $1.6 \mathrm{~d}$ & $11.8 \mathrm{~d}$ & $10.8 \mathrm{~d}$ & 40.4 abcd & $9.3 \mathrm{~cd}$ & $15.8 \mathrm{c}$ & $19.3 \mathrm{a}$ \\
\hline Serrana & $30.8 \mathrm{gh}$ & $43.4 \mathrm{ef}$ & $67.3 \mathrm{de}$ & $30.8 \mathrm{fgh}$ & $43.4 \mathrm{e}$ & $67.3 \mathrm{de}$ & $5.0 \mathrm{e}$ & 7.9 ef & $2.5 \mathrm{~d}$ & 20.0 cde & $16.0 \mathrm{~cd}$ & $41.4 \mathrm{abcd}$ & $11.7 \mathrm{bcd}$ & $8.2 \mathrm{~cd}$ & $22.6 \mathrm{a}$ \\
\hline Galil & $58.3 \mathrm{de}$ & $71.7 \mathrm{~cd}$ & 76.9 cde & $46.7 \mathrm{bcd}$ & $71.7 \mathrm{bc}$ & $76.1 \mathrm{bcd}$ & $20.8 \mathrm{~cd}$ & $35.8 \mathrm{bc}$ & $27.1 \mathrm{~b}$ & $40.0 \mathrm{bc}$ & $37.5 \mathrm{ab}$ & $44.0 \mathrm{a}-\mathrm{c}$ & $10.0 \mathrm{bcd}$ & $18.3 \mathrm{c}$ & $7.6 \mathrm{ab}$ \\
\hline Early Y. Premium & $46.7 \mathrm{efg}$ & $66.5 \mathrm{cde}$ & 89.1 bc & 36.7 efg & $61.7 \mathrm{~cd}$ & $86.6 \mathrm{abc}$ & $18.3 \mathrm{~cd}$ & $25.0 \mathrm{~cd}$ & $18.2 \mathrm{~b}$ & $30.0 \mathrm{bc}$ & $37.9 \mathrm{ab}$ & $61.9 \mathrm{ab}$ & $1.7 \mathrm{~d}$ & $12.4 \mathrm{~cd}$ & $5.0 \mathrm{ab}$ \\
\hline Arad & $55.0 \mathrm{ef}$ & $68.3 \mathrm{cde}$ & $90.0 \mathrm{bc}$ & $50.0 \mathrm{cde}$ & $68.3 \mathrm{bcd}$ & $90.0 \mathrm{ab}$ & $20.8 \mathrm{~cd}$ & $18.3 \mathrm{de}$ & $20.7 \mathrm{~b}$ & $35.0 \mathrm{bc}$ & $39.2 \mathrm{ab}$ & $60.2 \mathrm{ab}$ & $12.5 \mathrm{abcd}$ & $13.3 \mathrm{c}$ & $9.9 \mathrm{ab}$ \\
\hline Texas Grano $1025 \mathrm{Y}$ & $71.4 \mathrm{~cd}$ & $93.3 \mathrm{ab}$ & 96.6 a & $68.1 \mathrm{abc}$ & $85.0 \mathrm{ab}$ & 95.7 a & $31.0 \mathrm{bc}$ & $24.2 \mathrm{~cd}$ & $34.0 \mathrm{~b}$ & $42.1 \mathrm{~b}$ & $50.8 \mathrm{a}$ & $55.1 \mathrm{abc}$ & $22.7 \mathrm{ab}$ & $13.3 \mathrm{c}$ & $13.5 \mathrm{ab}$ \\
\hline Texas E. Grano 502 & $60.8 \mathrm{de}$ & $78.3 \mathrm{c}$ & $87.1 \mathrm{bc}$ & $52.5 \mathrm{cde}$ & $74.2 \mathrm{abc}$ & $82.9 \mathrm{abc}$ & $30.0 \mathrm{bc}$ & $35.0 \mathrm{bc}$ & $19.6 \mathrm{~b}$ & $25.8 \mathrm{bd}$ & $38.3 \mathrm{ab}$ & $45.2 \mathrm{abc}$ & $10.8 \mathrm{~cd}$ & $29.2 \mathrm{ab}$ & $23.1 \mathrm{a}$ \\
\hline Early Supreme & $85.8 \mathrm{ab}$ & $77.5 \mathrm{c}$ & $98.1 \mathrm{a}$ & $77.4 \mathrm{a}$ & $75.0 \mathrm{abc}$ & $93.0 \mathrm{a}$ & $54.7 \mathrm{a}$ & $34.2 \mathrm{c}$ & $81.0 \mathrm{a}$ & $27.9 \mathrm{bd}$ & $25.0 \mathrm{bcd}$ & $14.0 \mathrm{~d}$ & $13.4 \mathrm{ab}$ & $13.3 \mathrm{c}$ & $1.8 \mathrm{~b}$ \\
\hline Dehydrator No. 3 & $48.3 \mathrm{efg}$ & 45.8 ef & $66.8 \mathrm{de}$ & $39.2 \mathrm{def}$ & $43.3 \mathrm{e}$ & $66.8 \mathrm{de}$ & $15.0 \mathrm{~d}$ & $11.7 \mathrm{e}$ & $24.4 \mathrm{~b}$ & $11.7 \mathrm{~d}$ & $15.0 \mathrm{~cd}$ & $21.2 \mathrm{~cd}$ & $17.5 \mathrm{abc}$ & $20.0 \mathrm{c}$ & $18.7 \mathrm{a}$ \\
\hline AC50 & $33.9 \mathrm{fgh}$ & $50.0 \mathrm{def}$ & $94.4 \mathrm{ab}$ & $24.6 \mathrm{gh}$ & $50.0 \mathrm{de}$ & $93.9 \mathrm{a}$ & $14.4 \mathrm{~d}$ & $9.2 \mathrm{e}$ & $6.7 \mathrm{~cd}$ & 22.0 cde & $43.3 \mathrm{a}$ & $87.2 \mathrm{a}$ & $3.4 \mathrm{~cd}$ & $3.3 \mathrm{~d}$ & $0.0 \mathrm{~b}$ \\
\hline Granex 429 & 80.2 bc & $85.0 \mathrm{bc}$ & $78.0 \mathrm{~cd}$ & $74.4 \mathrm{ab}$ & $84.2 \mathrm{abc}$ & $72.9 \mathrm{~cd}$ & $34.7 \mathrm{~b}$ & $27.5 \mathrm{~cd}$ & $17.1 \mathrm{bc}$ & $34.7 \mathrm{bc}$ & $31.7 \mathrm{ab}$ & $50.7 \mathrm{abc}$ & $24.9 \mathrm{a}$ & $39.2 \mathrm{a}$ & $7.6 \mathrm{ab}$ \\
\hline Torrens White & $91.7 \mathrm{a}$ & $97.5 \mathrm{a}$ & 98.9 a & $85.0 \mathrm{a}$ & $95.8 \mathrm{a}$ & $96.4 \mathrm{a}$ & $51.7 \mathrm{ab}$ & $54.2 \mathrm{a}$ & $60.9 \mathrm{a}$ & $55.8 \mathrm{a}$ & $40.8 \mathrm{a}$ & $27.3 \mathrm{bcd}$ & $13.3 \mathrm{ab}$ & $22.5 \mathrm{bc}$ & $0.0 \mathrm{~b}$ \\
\hline Mean & 57.0 & 67.3 & 83.4 & 50.3 & 65.1 & 81.7 & 25.1 & 23.8 & 26.2 & 29.7 & 32.2 & 45.7 & 12.6 & 17.4 & 10.8 \\
\hline $\mathrm{CV}(\%)$ & 20.6 & 21.7 & 14.6 & 10.3 & 8.5 & 5 & 18.8 & 16.7 & 21.8 & 15.6 & 15.2 & 24.1 & 32.0 & 24.9 & 45.5 \\
\hline
\end{tabular}

${ }^{\mathrm{z}}$ Mean separation $(\mathrm{n}=12)$ within columns by Duncan's multiple range test, $P<0.05$.

dence averaged only $1.8 \%$. Such variation in disease incidence over years suggests a strong interaction between cultivar and environment. Based on visual symptoms at harvest, FR was the major disease in 1995 and 1996, whereas BR was predominant in 1997. Total rainfall during the growing periods was 110,103 , and $191 \mathrm{~mm}$ for 1995, 1996, and 1997, respectively (data not presented). Monthly rainfall patterns differed over trials. In 1997, most rainfall occurred in February and March during the critical bulbing stage.

STORAGE LOSSES OF ONIONS AND GROUPING OF CULTIVARS. ANOVA indicated that year by cultivar $(\mathrm{Y} \times \mathrm{G})$ interaction was significant (data not presented), therefore, storage loss data were analyzed and presented separately by year (Table 3). Cultivar effect was highly significant and the sum of squares for cultivar was more than double that observed for year (data not presented), indicating that cultivar influence was greater than that of year. Total storage losses of the 12 onion cultivars after 3 months of storage under ambient conditions was significantly greater in 1997 (57.3\% to $98.9 \%$ ) compared to 1995 (21.1\% to $91.7 \%)$ and
1996 (30\% to $97.5 \%$ ) (Table 3). Among the 12 cultivars, 'Red Pinoy' had the lowest storage losses in all 3 years (mean over years $=38 \%$ ) followed by 'Serrana' (mean over years $=47.2 \%$ ) (Table 3).

To determine the causes for the significance of the $Y \times G$ interaction, the 12 cultivars were grouped based on the degree and trend of storage losses over the years. Group 1 included 'Red Pinoy' and 'Serrana', which had the lowest overall storage losses. Storage losses in these two cultivars increased in 1997, but the increase was smaller than that of other cultivars. Storability was not significantly different between cultivars in Group 1. Group 2 included 'Texas Grano 1025Y', 'Arad', 'Galil', 'Early Yellow Premium', and 'Texas Early Grano 502', which had severe storage losses in 1997 compared to 1995 and 1996. The five cultivars within Group 2 differed significantly $(P \leq 0.05)$ in storage losses. Group 3 consisted of 'Dehydrator No.3' and 'Early Supreme', with lower storage losses in 1996 than 1995 and 1997. There was a highly significant difference between 'Dehydrator No.3' and 'Early Supreme'. Unique trends were observed

Table 4. Average bulb fresh weight (FW) and dry matter (DM) content of 12 short-day onion cultivars at harvest.

\begin{tabular}{|c|c|c|c|c|c|c|}
\hline $\begin{array}{l}\text { Cultivar } \\
\text { or line }\end{array}$ & \multicolumn{3}{|c|}{ Avg bulb FW (g) } & \multicolumn{3}{|c|}{ DM content $(\%)$} \\
\hline$\overline{\text { Red Pinoy }}$ & $145 \mathrm{gh}^{\mathrm{z}}$ & $164 \mathrm{e}$ & $157 \mathrm{~d}$ & $17.4 \mathrm{a}$ & $13.1 \mathrm{a}$ & $11.6 \mathrm{a}$ \\
\hline Galil & $308 \mathrm{~b}$ & $335 \mathrm{a}$ & $281 \mathrm{ab}$ & $6.9 \mathrm{ef}$ & $6.6 \mathrm{e}$ & $5.4 \mathrm{e}$ \\
\hline Early Y. Premium & $183 \mathrm{f}$ & $293 \mathrm{abc}$ & 206 c & $7.0 \mathrm{ef}$ & $7.7 \mathrm{de}$ & $6.2 \mathrm{~cd}$ \\
\hline Arad & $308 \mathrm{~b}$ & $300 \mathrm{abc}$ & $266 \mathrm{ab}$ & $8.8 \mathrm{~d}$ & $7.5 \mathrm{e}$ & $6.2 \mathrm{~cd}$ \\
\hline Early Supreme & $224 \mathrm{e}$ & $361 \mathrm{a}$ & $301 \mathrm{a}$ & $8.2 \mathrm{de}$ & $7.6 \mathrm{de}$ & $6.7 \mathrm{c}$ \\
\hline Dehydrator No. 3 & $161 \mathrm{fg}$ & 226 cde & $196 \mathrm{~cd}$ & $13.6 \mathrm{~b}$ & $12.5 \mathrm{ab}$ & $11.0 \mathrm{a}$ \\
\hline AC50 & $130 \mathrm{~h}$ & $185 \mathrm{de}$ & $63 \mathrm{e}$ & $10.9 \mathrm{c}$ & $10.9 \mathrm{bc}$ & $\mathrm{ND}^{\mathrm{y}}$ \\
\hline Granex 429 & $347 \mathrm{a}$ & $315 \mathrm{abc}$ & $305 \mathrm{a}$ & $6.2 \mathrm{f}$ & $6.4 \mathrm{e}$ & $5.3 \mathrm{e}$ \\
\hline Torrens White & $247 \mathrm{de}$ & $303 \mathrm{abc}$ & $309 \mathrm{a}$ & $7.8 \mathrm{def}$ & $7.2 \mathrm{e}$ & $6.1 \mathrm{ce}$ \\
\hline
\end{tabular}

${ }^{\mathrm{z}}$ Mean separation $(\mathrm{n}=3)$ within columns by Duncan's multiple range test, $P<0.05$.

${ }^{\mathrm{y}} \mathrm{ND}=$ not determined. 
Table 5. Phenotypic correlations between storage losses with other bulb characteristics in respective years.

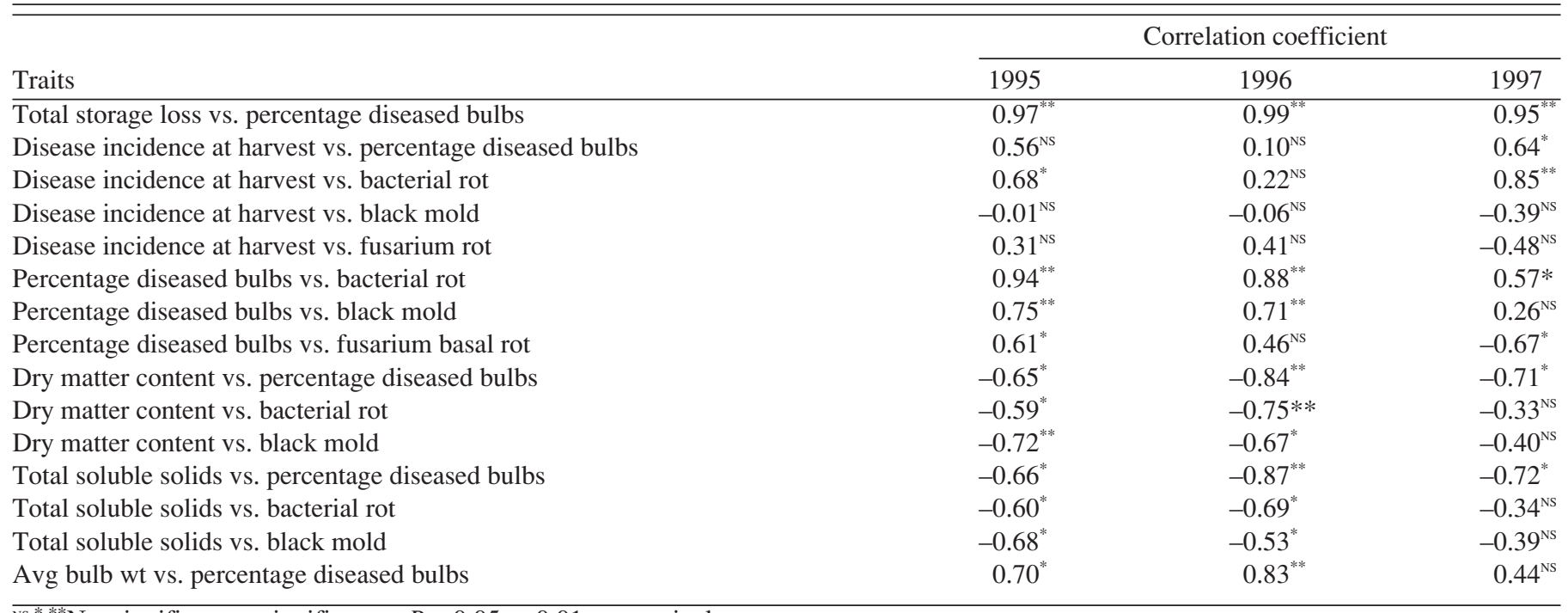

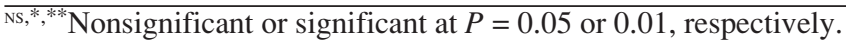

in three cultivars. 'Torrens White' exhibited consistently high storage losses in all 3 years. In contrast to the other cultivars, 'Granex 429' had less storage loss in 1997 than in 1995 and 1996, and 'AC50' had extremely high storage loss in 1997 compared with 1995 and 1996.

Storage Diseases. Postharvest diseases were the main cause of storage losses. The predominant diseases were BM, BR, and FR, with mean incidence over years of $36 \%, 25 \%$, and $14 \%$, respectively, although individual onion bulbs were often infected by more than one pathogen. Percentage diseased bulbs during storage was significantly higher in 1997 compared with 1995 and 1996. Cultivars within the same group tended to have similar BR, BM, and FR incidence across years. 'Early Supreme' and 'Torrens White' had relatively high BR incidence every year, with the highest BR incidence among cultivars of $81 \%$ and $61 \%$, respectively in 1997 . Among the 12 cultivars, AC50 showed constantly less FR incidence over 3 years, whereas 'Granex 429' and 'Texas Early Grano 502' were most susceptible to FR (Table 3).

Year and cultivar, and the $\mathrm{Y} \times \mathrm{G}$ interaction effect for $\mathrm{BM}$ incidence were all significant. Cultivars in Group 1, 'Red Pinoy' and 'Serrana', were less susceptible to BM and BR than the others throughout the 3 years of experimentation (Table 3). However, $19 \%$ of 'Red Pinoy' and $23 \%$ of 'Serrana' bulbs were susceptible to FR in 1997 (Table 3). In 1997, FR incidences in some good storability cultivars ('Red Pinoy' and 'Serrana') were high but were low in poor storability cultivars such as 'Early Supreme' and 'Torrens White' (Table 3). The high BR incidence in 'Early Supreme' $(81 \%)$ and 'Torrens White' $(61 \%)$ may have masked FR symptoms and, thus, underestimated the FR incidence.

Bulb Characteristics. Bulb FW and DM content data of all 12 cultivars are presented in Table 4. 'AC50' had the lowest bulb weight whereas 'Granex 429' had the largest among the cultivars studied. Bulb weight was influenced by $\mathrm{Y} \times \mathrm{G}$. 'Red Pinoy' had the highest DM while 'Granex 429' had the lowest among the 12 cultivars. DM content of 'Red Pinoy' decreased significantly in 1997 compared to the previous 2 years but it still ranked first among all cultivars tested. Differences in TSS and PA contents were significant among cultivars, but differences among years and their interaction were not significant (data not presented). Similar trends were observed for DM and TSS among cultivars. 'Red Pinoy' had the highest TSS, nearly double that of 'Granex
429' or 'Texas Early Grano 502'. PA content was significantly different between cultivars in 1995 and 1996, but differences were not significant in 1997. Among the cultivars evaluated, 'Dehydrator No.3' was the most pungent with PA content of 8.2 and $7.8 \mu \mathrm{mol} \cdot \mathrm{g}^{-1} \mathrm{FW}$ in 1995 and 1996, respectively.

RELATIONSHIPS AMONG STORABILITY, DISEASES, AND BULB CHARACTERISTICS. Correlations between storage losses with disease incidence at harvest, bulb characteristics, and storage diseases are shown in Table 5. Results of correlation between traits in 1995 and 1996 were similar with few exceptions. However, results in 1997 differed substantially from 1995 and 1996. Total storage loss was highly correlated with percentage diseased bulbs $(r>$ $0.95, P \leq 0.01$ over years) under high ambient temperature conditions. Disease incidence at harvest was only significantly correlated with bulb disease incidence in storage in 1997, but not in 1995 and 1996. Significant correlation was detected only between disease incidence at harvest and BR in storage in 1995 and 1997. Bulb characteristics such as DM, TSS, PA contents, and average bulb weight were not correlated with disease incidence at harvest and FR incidence in storage. However, DM and TSS were significantly correlated with percentage diseased bulbs as well as BR and BM incidence in storage in 1995 and 1996. In 1997, DM and TSS were associated with percentage diseased bulbs but not correlated to individual disease incidence in storage. Average bulb weight was positively correlated with percentage diseased bulbs in 1995 and 1996.

\section{Discussion}

Large variation in storability among short-day onion cultivars was observed. In the preliminary trial, 72 out of the total 130 entries had very poor storability. These results agree with Currah and Proctor (1990) who found that short-day onions in general have poor storability. White bulb onions were reported to have very poor storability (Owen et al., 1950; Schwartz and Mohan, 1995). In the present study, white cultivars such as 'Dehydrator No.3' and 'PSR11390' (included in the preliminary trial) had good storability, and bulb skin color was not associated with storage losses. Diseases were the main cause of storage losses. Storage losses were positively correlated with bulb weight. Significant correlation between these two parameters was ob- 
served in the preliminary trial and in both 1995 and 1996 experimental trials. The nonsignificant correlation in 1997 could have been due to high disease pressure during storage, particularly for BM. In general, large bulbs have softer texture and higher moisture, which may favor disease development (Chung, 1989).

Dry weather is favorable for harvesting and curing onion bulbs. Moreover, bulbs harvested during dry weather can be stored longer (Currah and Protor, 1990; Tucker and Drew, 1982). The very dry weather during bulb development in 1996, particularly in March, resulted in comparatively low disease incidence at harvest. On the contrary, the more than five times higher disease incidence at harvest in 1997 was probably due to heavy rainfall. Splashing rain can cause wounds and encourage entry of bacterial soft rot pathogens (Agrios, 1980). The 1997 trial data also showed a highly significant correlation between disease incidence at harvest and soft rot symptoms caused by bacterial pathogens in storage $(r=0.85, P<0.01)$ (Table 5). It is likely that moist bulbs in 1997 were infected by various bacterial pathogens without visible symptoms in the field and that the disease developed rapidly during storage. The sensitivity of cultivars to disease incidence at harvest appears to be different under unfavorable weather conditions in the field. For example, 'Texas Grano $1025 \mathrm{Y}$ ' and 'Arad' were the most sensitive to diseases incidence at harvest when high rainfall prevailed at the late growth stage. However, good storability cultivars, Serrana and Red Pinoy, had stable low disease incidence at harvest regardless of rainfall.

Under high temperatures and high humidities of the lowland tropics, sprouting is less of a problem, storage losses being due mainly to bulb decay caused by diseases. A high percentage of diseased bulbs are expected to result in high total storage loss, and the relationship between them was highly significant $(r=>0.95$, $P<0.01)$. BM, BR, and FR were the main storage diseases identified in this study, which are found commonly in other tropical countries. 'Red Pinoy' and 'Serrana' showed good storability and were tolerant to these diseases, particularly to BR. Storage losses were positively correlated with all three storage diseases. However, the correlation with FR was lower than with the others (Table 5). The low and nonsignificant correlation between disease incidence at harvest with BM in storage indicated that BM might have a long latent period or that infection occurred later during storage. Musa et al. (1973) reported that up to $80 \%$ of bulbs stored in Sudan were infected by BM. In Japan, BM caused more than $60 \%$ storage losses during summer (Tanaka, 1991). In our study, incidence of BM was higher than the other diseases during storage in all 3 years. Therefore, BM management is important for reducing storage losses in the tropics. Hayden et al. (1994) suggested an integrated control of BM for stored tropical onions, including seed treatment with chemicals, crop rotation, fungicide sprays to reduce inoculum levels, and regular ventilation of the storage room to maintain $\mathrm{RH}$ at $<80 \%$. Moreover, choice of cultivars resistant to BM and BR would improve overall storability.

In the 1997 crop, DM was smaller than in previous years, especially for those cultivars with higher DM, such as 'Red Pinoy' and 'Dehydrator No.3'. It is likely that high precipitation at the later stage of bulb development caused onions to absorb more water and reduced bulb DM content (Chung, 1989). Dry matter content associated with storability of onion is well known (Foskett and Peterson, 1950). Results of the present study also indicated that cultivars with higher TSS and DM had better storability and were less susceptible to storage diseases. Unlike DM and TSS, PA was not significantly correlated with storage losses in this study. Our study agrees with the findings of Pal et al. (1988) who found that the correlations between storage losses and PA was lower $(r=-0.44)$ than the correlation between storage losses with TSS and DM. TSS and DM were negatively correlated with storage losses when field conditions were dry at harvest, particularly in $1996[r=-0.87(P<0.01)$ and $-0.84(P<0.01)$, respectively]. However, under high rainfall conditions in 1997, correlations between individual storage diseases with TSS and DM were low. Based on results of this study, high DM or TSS at harvest could be used as a preliminary selection criterion to identify good storability, and bulbs should be evaluated further after storage.

In the present investigation, bulbs were stored under high temperature (mean maximum temperature up to $32{ }^{\circ} \mathrm{C}$ ) and high $\mathrm{RH}$ (mean maximum RH up to $98 \%$ ), conditions which are common in the lowland tropics/subtropics. Planting diseaseresistant cultivars or controlling the storage atmosphere can retard disease development and further improve storability of onions. 'Serrana' and 'Red Pinoy' had low disease incidence at harvest and low storage losses and disease incidences (BR and $\mathrm{BM}$ ) in storage in all 3 years (Table 3 ). Therefore, these two cultivars likely have some level of tolerance to various diseases in the field and in storage. Although 'Red Pinoy' had significantly higher DM than 'Serrana', their storability was not significantly different. These two cultivars have been selected as good storability donor parents in the onion breeding program of the AVRDC.

Understanding the cultivar by environment $(\mathrm{G} \times \mathrm{E})$ interaction of a specific trait is very important in plant breeding. Knowledge of the $\mathrm{G} \times \mathrm{E}$ interaction can help the breeder make decisions to optimize the breeding method and screening procedure. The significant $Y \times G$ interaction identified in this study was due to both changes in rank and magnitude of differences in storage losses among cultivars in different years. Therefore, the relative importance of years and cultivars will vary due to variable environmental conditions before harvest that may alter performance of different cultivars. Good storability cultivars, such as 'Red Pinoy' and 'Serrana', should be evaluated further in various locations and environments to determine whether they have good adaptability with low $\mathrm{G} \times \mathrm{E}$.

The negative correlation between DM and TSS with storage losses, as well as with incidence of BM and BR, is encouraging because they can be used as criteria in preliminary selection for good storability. It is likely that high DM cultivars with good storability have anatomical differences, which are less desirable for colonization by pathogens and, therefore, make them resistant to diseases. The positive correlation of storage losses with average bulb weight (Table 5) points to the need to develop large-size bulbs with good storability.

\section{Literature Cited}

Agrios, G.N. 1980. How plants defend themselves: Escape from disease, p. 17-37. In: J.G. Horsfall and E.B. Cowling (eds.). Plant disease. vol. V. Academic Press, New York.

Brice, J., L. Currah, A. Malins, and R. Bancroft. 1997. Onion storage in the tropics: A practical guide to storage and their selection. Natl. Res. Inst., Chantham, U.K.

Chang, W.N. 1979. Storability of onion and its improvement (in Chinese). Natl. Sci. Council. Republic of China Abstr. p. 315.

Chung, B. 1989. Irrigation and bulb onion quality. Acta Hort. 247:233237.

Currah, L. and F.J. Proctor. 1990. Onions in tropical regions. Natl. Res. Inst. U.K. Bul. 35.

Foskett R.L. and C.E. Peterson. 1950. Relation of dry matter content to storage quality in some onion varieties and hybrids. Proc. Amer. Soc. 
Hort. Sci. 55:314-318.

Handenburg, R.E., A.E. Watada, and C.Y. Wang. 1986. The commercial storage of fruits, vegetables, and florist and nursery stocks. U.S. Dept. Agr. Hdbk. 66.

Hayden, N.J., R.B. Maude, and F.J. Proctor. 1994. Strategies for the control of black mold (Aspergillus niger) on stored tropical onion. Acta Hort. 358:271-274.

Ko, S.-S. 2001. Identification of good storability in short-day onion and its mechanism of resistance to Aspergillus niger. PhD diss. Natl. Chung Hsing Univ., Taichung, Taiwan, Republic of China.

Lorbeer, J.W. and K.W. Stone. 1965. Reaction of onion to fusarium basal rot. Plant Dis. Rptr. 49:522-526.

Musa, S.K., H.A. Habish, A.A. Abdalla, and B.B. Adlan. 1973. Problems of onion storage in the Sudan. Trop. Sci. 15:319-327.

Owen, J.H., J.C. Walker, and M.A. Stahmann. 1950. Pungency, color, and moisture supply in relation to disease resistance in the onion. Phytopathology 40:292-297.

Pal, N., N. Singh, and B. Choudhury. 1988. Correlation and path coefficient studies in onion. Indian J. Hort. Sci. 45:295-299.

SAS Institute, Inc. 1993. SAS/STAT user's guide: Release 6.03 ed. SAS Inst. Inc., Cary, N.C.

Sato, Y. and M. Nagai. 1997. Varietal differences and genetic improvements of bulb qualities in spring-sown onion. J. Jpn. Soc. Hort. Sci. 66:339-345.

Schwartz, H.F. and S.K. Mohan. 1995. Compendium of onion and garlic diseases. APS Press, St. Paul, Minn.

Schwimmer, S. and W.J. Weston. 1961. Enzymatic development of pyruvic acid in onion as a measure of pungency. J. Agr. Food Chem. 9:301-304.

Suzuki, M. and J.A. Cutcliffe. 1989. Fructans in onion bulbs in relation to storage life. Can. J. Plant Sci. 69:1327-1333.

Tanaka, K. 1991. Studies on the black mold disease of onion bulbs caused by Aspergillus niger van Tieghem (in Japanese, with English summary) Bul. Fac. Agr. Saga Univ. 70:1-54.

Tanaka, M., K. Chee, and S. Komochi. 1985. Studies on the storage of autumn-harvested onion bulbs. I. Influence of storage temperature and humidity on sprouting during storage. Res. Bul. Hokkaido Natl. Agr. Expt. Sta. 141:1-16.

Tucker, W.G. and R.L.K. Drew. 1982. Postharvest study on autumn bulb onions. The effect of harvest date, conditioning treatments, and field drying on skin quality and on storage performance. J. Hort. Sci. 57:339348.

Vitanov, M. 1976. Effect of harvest dates and storage of onion on slippery skin infection (Pseudomonas alliicola Burk.) of onion bulbs. Gradinarska-i-Lozarska-Nauka 13:63-71.

Wall, M.M. and J.N. Corgan. 1994. Postharvest losses from delayed harvest and during common storage of short-day onions. HortScience 29:802-804.

Wright, P.J. 1993. Effects of nitrogen fertilizer, plant maturity at lifting, and water during field-curing on the incidence of bacterial soft rot of onions in store. N.Z. J. Crop Hort. Sci. 21:377-381.

Yoo, K.S., C.R. Andersen, L.M. Pike, and K. Sun Yoo. 1989. Determination of postharvest losses and storage life of 'Texas Grano 1015Y' onion. J. Rio Grande Valley Hort. Soc. 42:45-50. 